\title{
How Fiction Informed the Development of Telepresence and Teleoperation An Historical Perspective
}

\author{
Gordon M. Mair \\ Transparent Telepresence Research Group, \\ Department of Design, Manufacture, and Engineering Management, \\ University of Strathclyde, 75 Montrose Street, Glasgow, G1 1XJ, Scotland, UK \\ g.m.mair@strath.ac.uk
}

\begin{abstract}
This paper shows that many telepresence and teleoperation innovations and patents actually had their precursors in fiction and that this led the way for technological developments. This suggests justification for those companies that have invested, or are considering investing, in funding science fiction writers to provide future scenarios for their respective products and industries. The research leading to this conclusion has involved a search of patents, technical and scientific publications, and fictional works. The paper is mainly concerned with telepresence and teleoperation but aspects of virtual reality are included where the technological and literary concepts are relevant.
\end{abstract}

Keywords: Virtual reality, presence, teleoperation, science-fiction, telepresence history.

\section{Introduction}

For over a century fiction has speculated on a number of scenarios involving what we now call 'telepresence'. Throughout the same period technologies have developed that allowed the practical creation of aspects of telepresence. It is normal for authors of fiction, and particularly science fiction, to exploit existing and emerging scientific developments as a basis for their stories. However this paper suggests that in some instances fiction not only preceded but also inspired and led scientific and technological thinking in important aspects of telepresence and teleoperation. This is significant as the evidence adds credibility to the notion that close attention to science fiction by scientists, engineers, and commercial entities can provide vital inspiration for real world innovation and commercial development. For example a well-known mobile phone company once commissioned award winning science-fiction authors to write a book of short stories on the future of mobile communication [1]. This provided a source of possible product and application ideas as well as speculation on the social and cultural impact of developments.

The fiction of most relevance is of the type where the means for the achievement of the technology is described, sometimes called hard science fiction. The focus is 
therefore on technological manifestations of telepresence and teleoperation and the following paper examines how both fact and fiction created tributaries that led to the development of today's telepresence systems.

We can consider this topic using two time periods. Seminal fictional ideas and technical inventions that would lead to telepresence occurred very noticeably during the period 1876 to 1938 . However throughout these years the means whereby the fictional ideas could be manifested were very vague. For telepresence itself much of the directly relevant activity in both fact and fiction occurred from around the middle of the 20th Century, including what has been arguably called the Golden Age of Science Fiction between 1939 and 1959, to the present time of writing in 2013.

\section{$2 \quad$ The Tributary Years 1876 to 1938}

\subsection{Telephonoscopes and Nipkow Disks}

Significant audio transmission development began when Scottish born Alexander Graham Bell applied for his patent on the telephone "An Improvement in Telegraphy" in 1876 [2]. On the $24^{\text {th }}$ of December 1877 Thomas Edison filed his patent application for an "Improvement in phonograph or speaking machines" [3]. Since we are concerned here with telepresence it is interesting to see that the Scientific American of the $22^{\text {nd }}$ of December 1877, two days before Edison's filing, carried an article, including an illustration of his device and stating; "It is already possible by ingenious optical contrivances to throw stereoscopic photographs of people on screens in full view of an audience. Add the talking phonograph to counterfeit their voices, and it would be difficult to carry the illusion of real presence much further" [4].

These factual events quickly fired imagination and, considering that moving pictures were beginning to appear from a number of sources, Bell's and Edison's inventions inspired 'Punch' to publish an imaginative sketch on December the $9^{\text {th }} 1878$ of a "Telephonoscope" in which a mother and father converse live with their daughter thousands of miles away using what appears to be a super widescreen television and audio system more advanced than today's telepresence systems.

With regard to the beginnings of transmitted video, by 1884 existing knowledge of electricity and photoconductivity was put to use by a German university student Paul Gottleib Nipkow who invented the Scanning Disk when only 20 years old. Although a working system does not appear to have been built, this disk allowed the possibility of live transmission of very basic, low resolution, flickering images over a distance using an electro-mechanical system [5]. Not long after this in 1888 the story "In the Year 2889" by Jules Verne and his son Michel Verne was published [6]. In the story a very basic description is given of an audio-visual system similar to what we would call today a videophone.

\subsection{The Vision of Wells and Contemporaries}

"The Remarkable Case of Davidson's Eyes" [7] first published in 1895 saw H.G. Wells present the concept of someone sensing they were at a location remote from their physical body due, albeit very indirectly, to a type of technological mediation. Concerning Davidson, Wells says "In some unaccountable way, while he moved 
hither and thither in London, his sight moved hither and thither in a manner that corresponded about this distant island". The island was located in the Pacific Ocean on the other side of the world from London. This is perhaps the first description of immersive telepresence. "The Crystal Egg" [8] followed two years later in which Wells describes a system that allows a viewer on Earth to observe moving images of Mars a foretelling of today's unmanned Martian rovers. Of course, just as with today's robotic planetary explorers, a means of controlling the remote cameras would be necessary. However the first indication of how this could be achieved in practical terms came with a public demonstration a year later by Nikola Tesla in 1898 when he used "coded pulses via Hertzian waves" to radio control a model submersible boat in Madison Square Garden [9].

Returning to the theme of visual sensing, transmission, and display; our modern word television was first used by Par M. Constantin Perskyi in a paper titled "Television Au Moyen De L'electricite". This was presented to the $1^{\text {st }}$ International Electricity Congress at the World Fair in Paris on August $25^{\text {th }} 1900$ [10]. Then in June 1908 Nature published a letter sent by English physicist and inventor Shelford Bidwell which was titled "Telegraphic Photography and Electric Vision" [11]. Two weeks later a response by the Scottish electrical engineer Alan Archibald Campbell-Swinton was published and titled "Distant Electric Vision" [12]. It described how cathode ray tubes could be used for both acquiring an image at the transmission end and displaying an image at the receiving end for distant electric vision The letter said the following; "Referring to Mr. Shelford Bidwell's illuminating communication on this subject published in Nature of June 4 1908, may I point out that though, as stated by Mr. Bidwell, it is wildly impracticable to effect even 160,000 synchronised operations per second by ordinary mechanical means, this part, of the problem of obtaining distant electric vision can probably be solved by the employment of two beams of cathode rays (one at the transmitting and one at the receiving station) synchronously deflected by the varying fields of two electromagnets placed at right angles to one another and energised by two alternating electric currents of widely different frequencies, so that the moving extremities of the two beams are caused to sweep synchronously over the whole of the required surfaces within the one-tenth of a second necessary to take advantage of visual persistence". This is generally thought to have been the earliest description of how television could be obtained electronically at both transmission and reception by non electromechanical means.

However despite Campbell-Swinton's description the actual transmission of visual images did not begin until the 1920s. This occurred with the pioneering television work of Scottish inventor John Logie Baird using the electromechanical Nipkow Disk system. Baird and Day filed a patent application on the $25^{\text {th }}$ of July 1923 for "A system of transmitting views portraits and scenes by telegraphy or wireless telegraphy" and the patent was awarded the following year [13], forty years after Nipkow's patent. Baird's first demonstration of moving images was in what was then Selfridge's department store in London in 1925 and this was followed by a public demonstration to members of the Royal Institution in 1926. Like other inventors and scientists of his day Baird was known to have read H.G. Wells and therefore likely that he had read Davidson's Eyes and The Crystal Egg written almost thirty years earlier. 
On December the $29^{\text {th }} 1923$ the Russian-American Vladimir K. Zworykin filed his patent application for a "Television System" although it was not granted until 1938 [14]. On January the $7^{\text {th }} 1927$ the American Philo Farnsworth filed for patents for both a "Television System" [15] and a "Television Receiving System" [16] and was granted patents on them on the $26^{\text {th }}$ of August 1930. Despite Baird achieving many television firsts with his electromechanical system, e.g. first transatlantic television signal in 1928 and first live television transmission of the Epsom Derby in 1931, it was electronic television that was eventually adopted worldwide.

\subsection{A Brave New World}

In the realm of fiction we now have, in 1932, Aldous Huxley's utopian-dystopian fantasy of the future "Brave New World" [17]. Of particular relevance to the topic of immersive telepresence is his description of the "Feelies". The following quotes occur when the two protagonists visit the "Feelie" theatre. "The scent organ was playing a delightfully refreshing Herbal Cappricio .....". Then later "The house lights went down; fiery letters stood out solid as though self-supported in the darkness Three Weeks In A Helicopter. An All Super-Singing Synthetic-Talking, Coloured, Stereoscopic Feely. With Synchronised Scent-Organ Accompaniment". There follows a description of a simple but very sensual story in which, for example, "... the stereoscopic lips came together again, and once more the facial erogenous zones of the six thousand spectators in the Alhambra tingled with almost intolerable galvanic pleasure". The concept of stereoscopic images had been around since Wheatstone in 1838 [18] and they had been extremely popular in the Victorian era but Huxley's fictional use of olfaction and haptics as part of cinema entertainment is novel. This concept was to be reintroduced as a practical possibility 18 years later by Mort Heilig [19].

As we come to the end of this first period we see the concept of full telepresence being introduced through the medium of an anthropomorphic telepresence robot. This occurs within a short story "The Robot and the Lady" written by Manly Wade Wellman and published in Thrilling Wonder Stories in 1938 [20]. Here the protagonist uses a robot he has created as a surrogate to go on a date for him with a girl he has never met before. "My prize robot, tall, dashing would speak and act for me... I turned to where, on my desk, I had set up my controls. To my ears I clamped receivers, upon my eyes I bound the goggle like televisors that would coincide my viewpoint with that of the robot. A transmitter would place my voice upon those sculptured lips." then "My toe pressed a switch. At once, my vision-point changed. I seemed to sit on the bed's edge, gazing through the robot's pupils. I touched the keys, and rose to my but that was an illusion, born of years of such experiments. I remained silent, but the robot rose. I moved it across the floor, closed its fingers around the doorknob, and set it out into the hall. My hearing, vision and awareness went along with that excellent imitation of a young Adonis...". It transpires that the girl also sends a surrogate robot, but in the end, in a manner similar to what might happen today, they meet face to face in their real bodies and fall in love. 


\section{The Confluence Years 1939 to 2013}

\subsection{Heinlein and Waldo}

"Waldo" was a science-fiction story by Robert Heinlein writing under the pseudonym Anson MacDonald and published in Astounding Science Fiction in August 1942 [21]. The story title gave us a word that came to be used as an early generic term for all remotely controlled manipulating arms. I can find no evidence for scientific precursors to his concept of these telemanipulators, although they are loosely implied in earlier 'robot' stories like Wellman's mentioned above.

I suggest this is an atypical instance of a science-fiction writer coming up with a practical idea for technology before it was considered in any detail by scientists or technologists. The subject of the story is a highly intelligent individual called Waldo F. Jones who suffers from myaesthenia gravis. This has caused his muscles to be so weak he cannot comfortably live on Earth so he lives in the weightlessness of space in an orbiting satellite he has commissioned. He also builds master-slave manipulators, called primary and secondary "waldos". The secondaries are of various sizes some of which have hands "the size of a man's body" that can lift massive steel plates, and others are at the microscopic level for neurosurgery since he also uses small waldoes to create smaller ones and so on. This miniaturisation idea however was not new as Raymond Z. Gallun had earlier introduced the concept of microrobots building smaller microrobots that then built smaller microrobots down to the atomic level [22].

At one point in the story two visitors are going to see Waldo and one of them says that the satellite "...must be all of twenty-five thousand miles up". When they arrived "Waldo F. Jones seemed to be floating in this air at the centre of a spherical room. The appearance was caused by the fact that he was indeed floating in air. His house lay in a free orbit, with a period of just over twenty-four hours." Heinlein appears to be describing here a satellite in synchronous orbit from which he can communicate by radio with Earth since a geosynchronous orbit occurs at 22,236 miles. This is three years before the Arthur C. Clarke letter to "Wireless World" in February 1945 proposing geosynchronous communication satellites [23]. However it is possible Heinlein could have read of the idea in an English translation of a large part of Herman Potocnik's book “The Problem of Space Travel - The Rocket Motor". In the book the concept of a space station is described and the height of a geostationary orbit calculated. This translation appeared as a series in the American "Science Wonder Stories" throughout July, August, and September 1929 [24].

Where did Heinlein get the idea of 'waldos'? It seems that, although it is not an actual invention since he did not describe it in sufficient detail for it to be patentable, this is a real inventive concept not copied from existing technology. Since in the fictional story he titles his patent "Synchronous Reduplicating Pantograph" I carried out a patent search for real patents from before 1942 using similar type kinematic configurations. The only ones I found related to pantographs were primarily for engraving e.g [25]. However there are a number of patent applications relating to position controllers for paint spraying guns e.g. [26, 27] and an electro-mechanical 'Handle Control System' [28] for control of gun movements. Although indirectly related to some aspects of the waldos none of these are close to Heinlein's idea and even had he been aware of these patents his waldos remain apparently original in concept for the time. 
Subsequent to "Waldo" however, and due to the work in the emerging nuclear industry, remote handling became much more of a practical necessity. From the mid 1940 s the need to remotely handle radioactive materials in the nuclear industry led to the development of mechanical telemanipulators in places like the Argonne National Laboratories in the USA. These devices had bilateral control and by the 1950s electro-mechanical telemanipulators were in operation incorporating servo-control and force feedback [29]. This meant that the link between the user and the end effector of the manipulator could be a direct mechanical, electrical, or hydraulic connection. Goertz, one of the inventors in the previously mentioned Handle Control System, is prominent in the development of this equipment. His name appears on many relevant patents originally filed between the early 1940s and early 1960s. The early patents are related to control methods e.g. electro-mechanical [30] and electro-hydraulic [31], with the later ones relating to full handling systems e.g. [32].

A significant first occurred in 1943, this was the filing of a patent for a head mounted display [33]. This was by Henry J. De N. McCollum for a "Stereoscopic Television Apparatus" incorporating two miniature cathode ray tubes attached to the front of a pair of lenses held in a spectacle frame.

\subsection{Virtual Worlds and Distant Worlds}

As the second half of the twentieth century begins we find that much of the technology required at the 'home site' of a telepresence system is common to that of 'virtual reality' where the goal is to feel immersed in an artificial environment - in telepresence the display shows the real world whereas in VR it shows a computer generated world. The practice of creating a simulated immersive environment for entertainment has been around since the early $19^{\text {th }}$ Century in the form of cycloramas and the like, an interesting survey of these early simulations can be found in [34] However a leap forward in this concept appeared in Ray Bradbury's short story "The Veldt" which was published in the Saturday Evening Post in 1950 and subsequently included in his collection "The Illustrated Man" in 1951 [35]. In this story a nursery is described which anticipates the factual CAVE like environments of today although the nursery in Bradbury's story is much more sophisticated as it creates an artificial environment directly from the thoughts of its users. The children in the story had imagined an African scene that worried their parents, as the parents enter the room Bradbury writes: "The walls were blank and two-dimensional. Now as George and Lydia Handley stood in the centre of the room, the walls began to purr and recede into crystalline distance, it seemed, and presently an African Veldt appeared, in three dimensions, on all sides, in colour, reproduced to the final pebble and bit of straw. The ceiling above them became a deep sky with a hot yellow sun". And then: "Now the hidden odorophonics were beginning to blow a wind of odour at the two people in the middle of the baked veldtland..."

Then in 1952 in a short story titled "Bridge" the science-fiction author James Blish [36] describes a construction engineer carrying out work in the tempestuous and hostile atmosphere of Jupiter as though he is there, while in reality he is physically present on a satellite - "Jupiter V". His vicarious presence on Jupiter is achieved through technological mediation that includes the use of a head mounted display. Today, over six decades later, we would call this worker's experience telepresence. This is a short 
passage from the beginning of the story when the worker is just completing a spell of driving a squat "beetle" vehicle along the ice-bridge that is being built in an environment of howling storms and crushing pressures.

"In the momentary glare, however, he saw something - an upward twisting of shadows, patterned but obviously unfinished, fluttering in silhouette against the hydrogen cataract's lurid light. The end of the Bridge. Wrecked. Helmuth grunted involuntarily and backed the beetle away. The flare dimmed; the light poured down the sky and fell away into the raging sea below. The scanner clucked with satisfaction as the beetle recrossed the line into Zone 113 . He turned the body of the vehicle $180^{\circ}$, presenting its back to the dying torrent. There was nothing further he could do at the moment on the Bridge. He scanned his control board - a ghost image of which was cast across the scene on the Bridge - for the blue button marked Garage, punched it savagely, and tore off his helmet. Obediently the Bridge vanished." Then a few lines later: "The abrupt transition from the storm-ravaged deck of the Bridge to the quiet, placid air of the control shack on Jupiter V was always a shock. He had never been able to anticipate it, let alone become accustomed to it; it was worse each time, not better. He put the helmet down carefully in front of him and got up, moving carefully upon shaky legs; feeling implicit in his own body the enormous pressures and weights his guiding intelligence had just quitted."

Thus as well as a Jovian telepresence robot being suggested, we also have a head mounted display (HMD), augmented reality, and immersion withdrawal symptoms [37] all described almost a decade before the first physical HMD. I say this because I have found no evidence of the previously noted McCollum patent of 1943 actually being built. However a rapid succession of real world HMDs now appear. In 1957 Morton L Heilig filed a patent for a "Stereoscopic-Television Apparatus for Individual Use" and this was granted in Oct $4^{\text {th }} 1960$ [38]. In the $10^{\text {th }}$ of November 1961 edition of Electronics a report was presented on C P Comeau's and J S Bryan's Headsight television system for the Philco Corporation [39]. And finally, for displaying computer generated rather than televised images, we have Ivan Sutherland's 1968 paper in which he describes the development of "A head-mounted three dimensional display". This included hardware and software development to create an immersive experience for the user although at this time miniature CRTs still had to be used [40].

Today the concept of being able to immerse ourselves in computer generated environments to the extent that these virtual world appear real has long been in science fiction and popular culture from previously noted The Veldt in 1951, to Counterfeit World in 1965 [41] to Neuromancer in 1984 [42] to Snow Crash in 1992 [43] to the Matrix film in 1999, and now is quite common in books, films, and television dramas. However the ability to immerse ourselves in the real world at a remote location has not been so popular even although the concept appeared in fiction before 'virtual reality'. We have already noted the examples of telepresence from 1938 and 1952 and more recent examples would be in the graphic novel series "The Surrogates" [44] adapted as the 2009 film of the same name where the population in many cities live their lives through telepresence robots that are attractive perfected versions of their own bodies, similar to Wellman's story of seven decades earlier.

In the early stories it is interesting to note the use of each author's own terminology to describe their imagined technologies. In The Robot and the Lady we find "goggle like televisors", in Brave New world "feelies", in The Veldt "odorophonics", 
and in Bridge "ultraphone "eyes". Therefore although Persky's term television had been widely adopted half a century after it had been first introduced, other terminology useful to telepresence was still being developed. For example the term teleoperation was not used until 1966 by E.G. Johnsen [45], and the word "telepresence" was first observed in print when used by Marvin Minsky in an essay for OMNI magazine in June 1980 [46].

\section{Conclusion - Transparent Telepresence}

Today we have many elements developed but not yet what I term a 'transparent telepresence' system where the user experiences full presence in the remote environment $[47,48]$. However there are two relevant contemporary manifestations of earlier mentioned science fiction stories. The first is the teleoperation from a space station of a robot on Earth, as in the previously noted Heinlein story Waldo. This was reported in November 2012 [49] when a small robot on Earth was driven from the International Space Station. However in this NASA European Space Agency collaboration a laptop was used in the space station rather than a master arm. Secondly, extrapolating from the aforementioned 1938 Wellman story to the 2009 motion picture 'Avatar' we can imagine being fully immersed and in control of a surrogate body. One of the most relevant current research projects that approaches this ideal is the European Integrated Project VERE (Virtual Embodiment and Robotic Re-Embodiment) [50]. Some aspects of this attempt not only aural and visual telepresence within, but also mind control of a remote robot. This multi-million euro project began in June 2010 and will run for 60 months until 2015.

\section{References}

1. McClelland, S. (ed.) Future Histories. Pub. Nokia and Horizon House (June 1997)

2. Bell, A.G.: An Improvement in Telegraphy; US Pat. No. 174,465 (filed February 14 1876), (granted March 7, 1876)

3. Edison T.: Improvement in Phonograph or Speaking Machines; US Pat. No. 200,521 (filed December 24, 1877), (granted February 19, 1878)

4. Scientific American, pp. 384-385 (December 22, 1877)

5. Nipkow, P. G.: An electric telescope for the electric reproduction of illuminating objects. German Pat. No. 30105, (granted January 15, 1885) (retroactive January 6, 1884).

6. Verne, J., Verne, M.: In the Year 2889. first published in The Forum February 1888. Available in "The Works of Jules Verne" Published by Raleigh St. Claire Books (June 3, 2009)

7. Wells H.G.: The Remarkable Case of Davidsons's Eyes. Pall Mall Budget (March 28, 1895), available online from The Literature Network, http: / / www. online-literature.com/wellshg/2867/

8. Wells, H.G.: The Crystal Egg, The New Review (May 1897), web edition available online from University of Adelaide,

http://ebooks.adelaide.edu.au/w/wells/hg/crystal_egg/

9. Rosheim, M.E.: Robot Evolution. John Wiley and Sons Inc., New York (1994) 
10. Perskyi, P.M.C., Television Au Moyen De L'electricite. In: 1st International Electricity Congress, Paris (August 25, 1900)

11. Bidwell, S.: Telegraphic Photography and Electric Vision. Nature 78(2014), 105-106 (1908)

12. Campbell-Swinton, A.A.: Distant Electric Vision. Nature 78(2016), 151 (1908)

13. Baird J.L., Day: A system of transmitting views portraits and scenes by telegraphy or wireless telegraphy. UK Pat. No.GB222604 (October 9, 1924)

14. Zworykin, V.K.: Television System, US Pat. No. 2,141,059 (December 20, 1938)

15. Farnsworth, P.:A Television System US Pat. No.1,773,980. (August 26, 1930)

16. Farnsworth P.: A Television Receiving System. US Pat. No. 1,773,980 (August 26, 1930)

17. Huxley, A.: Brave New World.. First Edition 1932 Published by Chatto and Windus (London). Quote from pp. 145 - 147 Vintage Classics edition (2007)

18. http://www. stereoscopy.com/faq/wheatstone.html (retrieved March 9, 2012)

19. Heilig, M.L.: El Cine Del Futuro: The Cinema of the Future, originally published in Espacios 23-24 (1955), reprinted with translation Presence, Vol.1(3), pp. 279-294. MIT Press (1992)

20. Wellman, M.W.: The Robot and the Lady. Published October 1938 in 'Thrilling Wonder Stories' Text in this paper extracted from 'technovelgy' web pages,

http: / / www . technovelgy . com/ct/ content. asp? Bnum=1221 (March 15 2012)

21. Heinlein, R.: Waldo. originally published under the pseudonym Anson MacDonald in 'Astounding Magazine' (August 1942)

22. Gallun, R.Z.: A Menace in Miniature. Astounding Stories (October 1937)

23. Clarke, A.C.: V2 for Ionosphere Research?, in Letters to the Editor, Wireless World (February 1945$)$

24. http://en.wikipedia.org/wiki/Herman_Potocnik (accessed March 19, 2012)

25. Henkes, P.M.: Three Dimensional Engraving and Allied Pantograph Machine, US Pat. No. 2,161,709, (filed June 3, 1938), (granted April 30, 1940)

26. Pollard, W. L. V.: Position Controlling Apparatus US Pat No 2,286,571 (filed April 22,1938) (granted June 16,1942)

27. Roselund, H.A.: Means for Moving Spray Guns or Other Devices Through Predetermined Paths, US Pat No 2,344,108 (filed August 17, 1939) (granted March 14, 1944)

28. Hull, H.L., Hartman, W.C., Goertz, R.C.: Handle Control System, US Pat No 2,414,102 (filed July 23, 1941) (issued January 14, 1947)

29. Goertz, R.C., Thompson, W.M.: Electronically Controlled Manipulator. Nucleonics, 46-47 (1954)

30. Hull, H.L., Goertz, R.C.: Positional Control System, US Pat No 2,526,665 (filed January 24,1942) (granted October 24, 1950)

31. Peoples, J.R., Schelb, R., Goertz, R.C.: Servo System and Control Thereof, US Pat No 2,466,041 (filed March 30th 1943) (granted April 5, 1949)

32. Goertz, R.C.: Remote Control Manipulator, US Pat No 2,632,574 (filed December 16, 1949), (granted March 24, 1953)

33. De N McCollum, H. J., McCollum, T.: Stereoscopic Television Apparatus, US Pat No 2,388,170, (filed April 15, 1943), (granted October 30, 1945)

34. Judith, M.: Fly Me to the Moon: A Survey of American Historical and Contemporary Simulation Entertainments. Presence 6(5), 565-580 (1997)

35. Bradbury, R.: The Veldt, in 'The Illustrated Man', first published in UK 1952 by Rupert Hart-Davis Ltd., Flamingo Modern Classic edition, pp.15-32 (1995) 
36. Blish, J.: Bridge, Astounding Science Fiction, pp. 57-82. Pub. Street and smith publications, New York (1952)

37. Regan, C.: An Investigation into Nausea and Other Side-effects of Head-coupled Immersive Virtual Reality. Virtual Reality 1(1), 17-32 (1995)

38. Heilig, M.L.: Stereoscopic-Television Apparatus for Individual Use, US Pat No 2,955,156 (filed May 24, 1957) (granted October 4, 1960)

39. Comeau, C.P., Brian, J.S.: Headsight Television System Provides Remote Surveillance. Electronics, pp. 86-90 ( November 10, 1961)

40. Sutherland, I.E.: A head-mounted three dimensional display. In: Fall Joint Computer Conference, AFIPS Conference Proceedings, vol. 33, pp. 754-764 (1968)

41. Galouye, D.F.: Counterfeit World,, Pub. Victor Gollancz Ltd. (1965)

42. Gibson, W.: Neuromancer, Pub. Victor Gollancz Ltd. (1984)

43. Stephenson, N.: Snow Crash, Pub. Bantam Books (1992)

44. Venditti, R., Weldele, B.: The Surrogates, graphic novel series, Pub. Top Shelf Productions ( 2005-2006)

45. Johnsen, E.G.: Telesensors, teleoperators and telecontrols for remote operations. IEEE Transactions on Nuclear Science NS13, 14-21 (1965); (Originally presented at the 12th Annual Nuclear Science Symposium,San Francisco, California, October 18-20, 1965).

46. Minsky, M.: Telepresence. OMNI Magazine (June 1980)

47. Mair, G.: Transparent telepresence research. Industrial Robot 26(3), 209-215 (1999)

48. Mair, G.: Towards Transparent Telepresence. In: Shumaker, R. (ed.) HCII 2007 and ICVR 2007. LNCS, vol. 4563, pp. 300-309. Springer, Heidelberg (2007)

49. http://www. nasa.gov/home/hqnews/2012/nov/HQ_12-391_DTN. html (retrieved February 27, 2013)

50. http: / /www. vereproject. eu (retrieved February 25, 2013) 